\title{
Barn + bok $=$ ? \\ Hva kan skje når barn møter bok?
}

Tordis Irene Fosse - tordis.fosse@senior.hioa.no

Oslo and Akershus University College of applied sciences

Kari Hansen-Møllerud - karih@getmail.no

Oslo and Akershus University College of applied sciences

Helene Valvatne - helene.valvatne@senior.hioa.no

Oslo and Akershus University College of applied sciences

\section{Abstract}

I denne artikkelen benytter vi oss av både fiksjon og sakprosa for å skrive om hvordan barnehagen kan arbeide med litterasitet ${ }^{1}$ med utgangspunkt $i$ bildebøker. Ved å fabulere $i$ fortellings form utforsker vi muligheter som kan ligge i ei bokstund. Deretter kommenterer og reflekterer vi over fortellinga, og redegjør for forskning om tidlig litterasitet. Det er denne forskningen, og en overbevisning om at bildebøker byr på helt spesielle muligheter $i$ barnehagens arbeid med litterasitet, som har inspirert oss til utforsking gjennom fiksjon. I dagens debatt om forebygging av lese-og skrivevansker argumenteres det for kartleggingsverktøy, standarder, språkpakker og læringsmål i barnehagen. Vi vil heller etterlyse innsikt i hvordan barns litterasitet kan komme til uttrykk og utvikle seg gjennom opplevelser og aktiviteter knytta til barnelitteratur.

Fortellinga handler om ei gruppe femåringer og en barnehagelærer som leser bildeboka Snill av Gro Dahle og Svein Nyhus². Vi håper artikkelen vil inspirere til kreativt FoU-arbeid, med rapporter som gir mye plass til fortelling, oppdikta og/eller fra virkeligheten.

Key words: Utforskende fiksjon; Litterasitet; Barnehage; Dialogisk bokstund; Bildebøker

\section{Vi dikter ei bokstund}

Det er bokstund i Kleiva barnehage. Seks femåringer sitter forventningsfulle foran barnehagelærer Janne, mens den faste bokstundsmusikken toner ut. Janne sitter i høytlesningsstolen, som denne dagen er drapert med et rosa silkestoff. I vinduet dingler en uro med små soler. Janne har en stor,

\footnotetext{
${ }^{1}$ Vi har valgt å bruke ordet "litterasitet" i stedet for «skriftspråkskompetanse» eller "skriftkyndighet", som har vært mest vanlig i norsk faglitteratur om tidlige skriftspråksrelatert kompetanse. Ordvalget begrunnes under overskriften «Tidlig litterasitet: perspektivutvidelser i fagfeltet».

${ }^{2}$ Fortellinga er videreutvikling av ei fortelling i en tidligere artikkel av to av forfatterne (Hansen-Møllerud og Valvatne 2004).
} 
svart stoffbærepose med seg. Barna vet at der ligger den nye boka som de skal lese denne mandagsmorgenen.

- Kan dere gjette hvorfor stolen min er rosa i dag? spør Janne.

- Lese rosa bok, foreslår Samantha.

- Ja, boka vi skal lese denne uka, er rosa, bekrefter Janne, men den er også litt gul, som solene i vinduet, og litt blågrønn. Nesten samme farge som genseren jeg har på meg.

Det blir en del snakk om hvem av barna som har slike farger på seg denne dagen, og om andre farger på klærne. Så åpner Janne bæreposen og en samling vakre, rosa bøker åpenbarer seg. Det er sju eksemplarer av boka Snill av Gro Dahle og Svein Nyhus. Barna får hver sin bok, og ei er til Janne. Ingen åpner boka ennå. Først skal de undersøke den utenpå. Slik er det alltid når de begynner på ei ny bok.

- Den jenta ser litt redd ut, sier Ingrid, og peker på jenta på forsida av boka. Er hun redd?

Jenta på forsida av boka har lyst hår, rosa kjole med hvit krage, hvite knestrømper, store øyne, en bitteliten munn og tynne armer og bein.

- Kanskje, sier Janne. Men jeg syns hun ser snill ut også.

- Der står snill, sier Martin, og peker på boktittelen, som er skrevet med håndskrift.

- Ja, boka heter Snill, svarer Janne

- Det er sånne svingete bokstaver som mamma skriver, sier Ingrid begeistra.

Flere kan fortelle at mor, far eller søsken skriver slike bokstaver, men de andre bokstavene på forsida, som er laga av rette streker, er lettere å kjenne igjen. Aleksander, Samantha og Hassan kjenner igjen sin egen bokstav, og Mari, som ikke pleier å si så mye, kjenner igjen hele navnet til mamma: GRO.

- Ja visst, Mari! Der står det Gro! Skal jeg lese alt som står her?

Mari nikker og flere av de andre er også interessert. Janne leser langsomt, mens hun peker: Snill, Gro Dahle, Svein Nyhus, Cappelen. Nå blir det mye å snakke om. Flere av barna kjenner noen som heter Gro og Svein, og Martin vet om en som heter Dahle til etternavn. De skjønner at Nyhus er etternavnet til Svein. Men Cappelen er et rart ord. Janne kan fortelle at Cappelen er navnet på forlaget som har gjort boka ferdig etter at forfatteren, Gro Dahle, og illustratøren, Svein Nyhus, har skrevet og tegnet alt som skal være med. Forlag, forfatter og illustrat ør er etter hvert blitt kjente ord for barna. Janne forteller litt om Gro Dahle og Svein Nyhus, at de er gift med hverandre, har tre barn og en gris som pleier å sove i senga deres.

- Se, stor mann, roper Hassan plutselig. Han har snudd boka og begynt å se på baksida. Janne og alle barna snur også boka nå, og ser på mannen. Han har blågrønne klær, står og bøyer seg, og har noe langt mellom knærne.

- Han har uniform, sier Martin. Kanskje han er politimann.

- Han ser litt skummel ut, syns Ingrid. Kanskje Lussi er redd for han? 
Det er bokstaver her også, mange små, som ikke likner på noen av bokstavene på forsida. Janne leser:

Lussi er så snill, så snill.

Så snill at hun en dag blir borte.

Barna ler. Det går vel ikke an!

- Det er faktisk det som skjer i denne boka, sier Janne. I bøker, der går alt an. Alt som ikke går an $\mathrm{i}$ virkeligheten, det kan gå an i bøker. Akkurat som i eventyrene.

Nå er barna spente og klare for å åpne boka. De finner først helt svarte ark, men kommer raskt til tittelsida, og Martin kjenner straks igjen ordene som sto på forsida.

- Der står snill, sier han og peker. Og der står Gro Dahle, og der Svein Nyhus og der Cappelen.

Aleksander blar tilbake til forsida for å sammenlikne, men de andre er ivrige etter å få vite mer om Lussi, så Janne blar om til første oppslag ${ }^{3}$. Her sitter Lussi og skriver ved et stort bord. Det gjør hun også på neste oppslag, men på det tredje sitter hun i sofaen og smiler, mellom en mann og ei dame som leser. Barna lurer svært på når hun blir borte, så de blar raskt videre, helt til de kommer til et bilde der de først ikke kan se henne. Men så oppdager Hassan henne.

- Ja, der er hun jammen, sier Janne. Oppe på veggen der, under klokka! Hun er så liten at jeg så henne ikke først. Hvorfor er hun høyt oppe på veggen, tro? Hun ser litt redd ut, syns jeg.

- Men hun er ikke borte, sier Aleksander. Når blir hun borte? De blar videre for å se. Hvor er Lussi?

- Der! Der! For hvert nytt bilde er de opptatt av hvor Lussi er, og hvordan hun ser ut, men de legger også merke til mye annet i bildene. Blant annet ser de igjen mannen fra baksida av boka. Der står han oppreist, og nå kan de se at det han holdt mellom knærne, er en lang kikkert. De ser ham også igjen på et annet bilde, der han står sammen med mange barn og peker på Lussi. Der ser han sint ut og enda mer skummel enn på baksida av boka.

- Skal vi bla tilbake til begynnelsen og lese? spør Janne.

- Ja! Alle er enige og blar tilbake til første oppslag, der Lussi sitter og skriver ved et stort bord.

Janne begynner å lese:

Se på Lussi!

Se på Lussi!

Se så stille hun er!

Stille stille som hvitt kritt og tynt papir.

Stille som blanke glass i et skap

- Glass i skap lager ikke lyd, men kritt kan skrape, sier Martin.

${ }^{3}$ I bildebøker hører ofte to og to sider sammen, og det er derfor vanlig å si at en blar om til neste oppslag i stedet for til neste side. Betegnelsen oppslag dekker helheten en slår opp til når en blar om. 
- Stille som, stille som, stille som ...? sier Janne.

- Stille som mus, hvisker Samantha.

- Stille som en katt som vil fange mus, sier Aleksander ivrig. Katten min satt helt stille!

- Stille som ei brødskive, sier Ingrid plutselig.

- Som fiskeboller!

- Som pølser!

- Som pizza!

- Nå har dere jammen laga et dikt, sier Janne. Hør:

Stille som glass i et skap

Stille som mus

Stille som en katt som vil fange mus

Stille som ei brødskive

Stille som fiskeboller, som pølser, som pizza

Janne «leser» og smiler, og for hver ny sammenlikning ser hun på den som fant på den.

Lussi er ikke bare stille, men også snill og flink. Janne leser om hvor riktig hun gjør alt på skolen, om rene og passe lange negler, om grundig tannpussing og om munnen «som aldri sier noe som helst før den blir spurt». Barna lytter, mens de ser på bilder av Lussi som skriver, og Lussi som smiler mellom lesende foreldre i sofaen.

Bare snill og flink og ti og tjue tusen millioner stille.

- Veldig mye stille, sier Samantha lavt.

- Ja, sier Janne, og fortsetter:

Så stille

at plutselig en dag forsvant hun bare.

- Det var rart, sier Martin.

- I bøker kan alt gå an, sier Janne. Og hvis du aldri sier noe, da er det kanskje ingen som ser at du er der?

- Men hun ble ikke helt borte, protesterer Hassan. Vi så hun.

- Ja vi så henne, smiler Janne. Men den store mannen så henne ikke, sjøl om han brukte kikkert. Hun var nok helt borte for både han og de andre ei stund. Hør bare! Hun leser videre, om Lussi som var så flink og stille at alle glemte at hun var der.

Til slutt gled hun inn i veggen og ble borte.

Ikke bare litt borte.

Ikke bare borte noen minutter.

Ikke bare ute på jentedoen.

Men helt borte,

helt bortebortebortevekk borte

- Bortebortebortebortebortevekkvekkvekk, sier Ingrid. Kvekkvekk.

- Og når Lussi er vekk, blir det skrekk, sier Janne, og fortsetter: 


\begin{abstract}
Lussi? ropte moren.
Lussi? ropte faren.

Lussi? ropte læreren.

Lussi? ropte alle de andre barna.
\end{abstract}

Men ingen fant henne,

Ikke engang den store vaktmesteren.

- Der vaktmesteren, sier Hassan, og peker på en mann med stort nøkleknippe i beltet.

- Og det er sikkert læreren. Martin peker på en mann som står og roper.

- Ja, det er nok læreren, sier Janne. Og han med alle nøklene er sikkert vaktmesteren. Han kan låse opp alle dørene på skolen og lete alle steder. Og likevel finner han visst ikke Lussi?

For Lussi satt fast der inne i veggen.

Og da hun prøvde å åpne munnen,

klarte hun det ikke.

Hun kunne bare blunke.

Men det var det ingen som så

og ingen som hørte.

- Det går ikke an å sitte fast inne i veggen, sier Martin bestemt.

- Alt går an i bøker! sier Mari. Stakkars Lussi!

- Ja, stakkars. Janne er enig. Tenk, hun sitter fast inne i veggen, og ingen kan se eller høre henne.

- Stakkars mamman og pappan også, sier Ingrid. De blir nok lei seg når de ikke finner henne.

Og det blir de, får barna vite når Janne leser videre, om mora som gråt og faren som ble streng, om alle på skolen som «ropte og skrek så ingen så eller hørte noen ting», og om brannmenn som lette etter henne alle steder, til og med høyt, høyt oppe på et hustak. På dette oppslaget ser de den skumle mannen med kikkerten.

- Han tror Lussi er langt borte, sier Martin. Og der er det ei dame som har kikkert også. Janne smiler, og fortsetter å lese om Lussi inne i veggen, som prøver å rope, men ikke klarer det.

For ordene satt fast i stemmen.

Og stemmen satt fast i munnen.

Og munnen satt fast i smilet.

Og smilet kunne bare smile.

- Alt satt fast! sier Janne. Kanskje noen av dere har prøvd å si noe engang, og ikke fått det til? Hun blar om til neste oppslag, med bilde av Lussi som smiler stivt, midt inne i ei veggklokke.

Ser du Lussi nå?

Ser du Lussi inni veggen?

Stakkars Lussi. Der må Lussi sitte i hundrede år.

Ti tusen millioner sekunder.

For Lussi er fange i veggen.

- «Tornerose sov i hundre år!» sier Ingrid.

- Ja, sier Janne, og Lussi er like stille inne i veggen som Tornerose var da hun sov i hundre år. Nå skal 
dere høre hvor stille hun er:

Så stille så stille

som tenner og kniver og blankt metall.

Stille som pigger og nåler og

sylskarpe negler.

Stille som skruer og spiker.

Stille som stikk.

Hun leser langsomt, og slik at både rytmiske gjentakinger, bokstavrim, spesielle sammenlikninger, sylskarpe sammenstillinger og den skumle stille-før-stormen-stemningen framheves. Barna lytter og alle ansiktene er alvorlige. De blar ivrig om til neste oppslag sammen med Janne, og nå smiler ikke Lussi lenger. Det skjer noe:

Da kjenner Lussi det kile i halsen.

Det kribler og surrer.

Det freser og suser, bruser og sprenger.

Et rop arbeider seg fram i magen.

Og ropet vokser seg stort i munnen.

Og smilet sprekker i ti tusen biter.

Og Lussi reiser seg opp og roper.

Og Lussi skriker og hyler og gaper.

- Når jeg blir sint, suser og bruser det i hodet mitt, sier Aleksander.

- Kanskje du roper og skriker også? lurer Janne på.

- Noen ganger.

- Dokka mi skriker noen ganger, sier Mari.

- Når du klemmer henne på magen? spør Janne. Mari nikker.

Ingrid blar om til neste oppslag, og når Janne også blar om, gjør alle det. De ser på bildet som er der. Lussi skriker fortsatt, og hun slår rundt seg med fem armer! Det står ei jente og ser på henne. Hun ser redd ut.

- Hva står det der? spør Ingrid.

- Der står "hammer"! Martin peker på et ord på første linje i teksten ved siden av bildet. Javisst, sier Janne og leser:

Hun blir til en hammer. Hun slår og hun slår.

Hun blir til en syl og et bor og en hakke.

Hun stanger med hodet. Hun blir til en okse.

Hun slenger med halen. Hun blir til en kølle.

Hun blir til en slegge. Hun spenner og sparker.

Hun blir til en plog. Hun brøyter seg fram.

Og murpussen suser.

Hun blir til en saks

og klipper tapeten.

Hun tramper til gulvet begynner å bølge. 
- Alt går an i bøker! sier Janne. Akkurat som vi kan leike alt mulig! Skal vi leike litt før vi leser mer?

Janne leser sakte og stykkevis en gang til om alt som Lussi blir, og ungene får være alt dette ute på golvet. Noen kommer på enda mer som de kan være når de er sinte: en bulldoser, en løve, tordenvær. Når ungene sitter stille igjen og puster ut, legger Janne til de nye forvandlingene som de har funnet på:

Hun blir til en bulldoser.

Hun blir til en løve og brøler og brøler.

Hun blir til et tordenvær og braker og bråker.

På neste oppslag har Lussi bare to armer å slå med, men hun skriker visst enda høyere. Og hun løper. Og ei jente og en gutt løper også, og de ser fryktelig redde ut. Og en mann gjemmer seg. Og bøker og ei $d \varnothing r$ og mye annet fyker rundt i rommet.

- Hva er det som skjer her? undrer Janne, og leser:

Er det rart at læreren blir redd?

Du store all verdens land og rike, sier læreren da

og gjemmer seg bort i det innerste hjørnet.

I den innerste kroken av alle kroker, der sitter læreren. Stakkars liten.

- Hvor er den innerste kroken i rommet vårt? spør Janne.

Ungene peker, og Janne gjemmer seg og ser redd ut. Så kommer hun tilbake.

Og hva skjer nå? Lussi sitter ikke fast lenger!

For Lussi kommer rett ut av veggen

så flisene flakser og murstøvet fyker.

Og Lussi er tre ganger tre

og dobbelt så synlig.

Og Lussi roper så taket rister:

\section{Nå er det nok!}

roper Lussi.

Og det er det.

Mer enn nok.

Det skjønner vel alle.

- Mer enn nok, gjentar Samantha.

- Ja, sier Janne. Nå er det mer enn nok. Nå vil ikke Lussi være snill og flink og stille mer. Skal vi rope «Nå er det nok!» alle sammen, akkurat som Lussi? Det er ikke innestemme. Men noen ganger er det lov å bruke utestemme inne. Når det er nødvendig.

Så roper alle «Nå er det nok» i kor og hulter til bulter. Mari og Samantha roper høyt.

- Lurer på hvordan det går nå, sier Aleksander. Får Lussi husarrest? Men nei! 
Barna blar om, og kommer til oppslaget der den skumle mannen står og peker på Lussi. Han ser sint ut, og bak ham står mange barn og stirrer på Lussi, som står midt på golvet og skriker. Vaktmesteren og ei dame stirrer også, og to menn gjemmer seg.

Alle ser på Lussi, sier Aleksander.

- Ja, nå ser de henne. Janne leser om alle som stirrer på Lussi.

Barna stirrer også, på bildet, og på Janne, som fortsetter å lese:

For nå er Lussi ute av veggen.

Og videre:

Se på Lussi!

Det er noe til flekkete jente.

Det er jente med sagflis i håret.

Det er jente som kan velte stoler!

Det er jente som kan rope og skrike!

Hun vekker bjørner opp av dvale.

Skremmer faren inn i skapet.

Du kan høre henne helt til Finland.

Jammen kan du det.

- Les det en gang til, sier Aleksander, og Janne følger oppfordringen.

- Vekker bjørner opp av dvale, gjentar Martin. Hva er dvale?

- Søvn, svarer Janne. Vi sier at bjørnen ligger i dvale når den sover i hiet sitt om vinteren.

- Det går ikke an å rope så høyt at en bjørn langt inne i skogen våkner, sier Martin.

- lallfall ikke så høyt at de hører det helt til Finland, mener Ingrid.

- I bøker kan alt gå an, slår Aleksander fast.

Janne blar om til neste oppslag. Det er visst noe rart med veggen her. Lussi stirrer på den, kan de se.

- Hva er det Lussi ser på? Undrer Janne, og når hun leser videre, er hun stillere i stemmen, og leser saktere:

Men hva nå da, Lussi?

Lussi roper ikke lenger.

Lussi velter ikke flere stoler.

Lussi tramper heller ikke.

Hysj!

Lussi lytter.

Hysj!

- Lussi kan være like stille nå som hun var før, sier Janne. Når hun vil være stille. Noen ganger må vi rope, og noen ganger er det best å være stille. Nå vil Lussi være helt stille, for det er en liten lyd hun 
vil høre. Janne leser så stille så stille, så det poetiske kommer til sin rett: gjentakinger, paralleller og etter hvert bare et lite setningsemne om gangen, som får stå der og dirre:

Alle sammen ser på Lussi.

Lussi stirrer inn i veggen.

Hysj!

Liten lyd.

Liten stemme.

Lite pip.

Lite rop.

Hva var det, hvem? Hvor?

Hvem kommer, tro? De blar om, og ser mange små jenter som er litt inni veggen og litt utenfor. Nå trenger ungene virkelig erfaringen at alt går an i bøker. De lytter spent når Janne leser:

\section{Se på veggen! \\ Det stikker fram et lite hode.}

Et lite smil, en liten nese.

Og så én til, og én til:

Lille Bitten.

Lille Lene.

Flere navn, og så:

Ser du at de titter fram?

Kikker ut.

Kryper ut.

En og to og tre og fire og fem.

Og til slutt:

Bare kom, du, sier Lussi

og rekker hånden fram.

Og bittelille Madeleine

som er nesten gjennomsiktig

triller ut,

tå for tå.

Tipp tapp to.

Men det er ikke slutt ennå. For på neste oppslag kommer det ei gammel dame ut av veggen.

- Hvem er det? lurer Ingrid på.

- Les mer, sier Martin. Janne gjør som han sier:

Men hva nå da?

Se på veggen!

Der kommer jammen oldemor!

Selveste Margit Augusta Johanne!

Var det der du var hele tiden? sier faren.

Vi trodde du var borte! sier moren

og hjelper oldemor ut av veggen. 
Den gamle stilken! Den krumme kroppen!

Se, hun smiler! Se hun vinker!

$\mathrm{H} \varnothing \mathrm{r}$, hun knirker!

Å Lussi, sier oldemor.

Det er jenta si, det,

som kan sprenge vei i veggen!

- Hvordan har de kommet inn i veggen? Hvorfor er de der? spør Martin.

- Hva tror dere? spør Janne.

- De var helt stille, sier Samantha. Og så kom de i veggen.

- Men hvordan kan de komme ut? lurer Ingrid på.

Det blir stille ei stund, før Martin svarer: Lussi har sprengt vei som de kan bruke!

- Jammen har hun det, smiler Janne.

De blar om til siste oppslag. Bildet viser Lussi som piller seg i nesa, vaktmesteren som feier golvet, og en liten gutt som kikker på noe av alt som ligger der.

- Vil dere høre det siste som står i boka, sier Janne. Det vil de, og hun leser:

Og så da?

Kanskje det fins andre vegger?

Kanskje det fins flere

helt usynlige jenter?

kanskje noen står og venter?

Kanskje det fins oldem $\varnothing$ dre

som sitter helt fast?

Hva med dem, tenker Lussi og gjesper

så høyt og så langt

at kjevene knaker

og jekslene synes.

Så dypt

at de som ser etter,

kan se helt til Kina.

For det er noe til sliten jente.

- Går det an å se helt til Kina inne i munnen? spør Aleksander..

- Alt går an i bøker, sier Martin og Mari i kor.

Janne ler. - Ja visst! I bøker går det an å gjespe så dypt at de som ser etter, kan se helt til Kina. Og det går an å spise mer enn noen har spist noen gang. Husker dere boka om Mons matglad?

- Ja! Mari svarer først, og de andre følger etter, i kor

- Han spiste hele båt, husker Hassan,

- Og sola, kommer det fra flere av de andre.

- Nå er Lussi minst like sulten som Mons Matglad, sier Janne. Hun orker ikke å tenke mer på andre vegger, usynlige jenter og oldemødre som sitter fast. Hun vil bare spise, og spise mye! 
De får greie seg selv, tenker Lussi.

For nå vil Lussi hjem og spise.

Og det er noe til sulten jente!

Det er jente som har matlyst!

Kalv og ku og sau og gris

og fisk og kål og gulrot

og femten lange, tynne pølser,

det vil Lussi gjerne spise.

For det er jenta si det.

- Jeg også sulten, sier Hassan.

- Det passer fint, for nå er det mat, sier Janne. Vil du ha femti gulrøtter og hundre brødskiver?

Vi velger å stoppe vår oppdikta fortelling her, men tenker oss at Janne og barna ikke slipper tak i Snill når bokstunda er over. Om vi hadde fortsatt å fortelle, ville vi ha latt Janne plassere boka på et lett synlig sted og flere eksemplarer tilgjengelig i bokhylla, så barna kunne hente dem fram, bla i dem, gjenkjenne bokstaver, ord og uttrykk, se på bildene og fortelle om Lussi for hverandre, Janne og andre. Vi ville nok også tatt med noe om leik, for eksempel at barna leiker Lussi som er altfor stille, Lussi som roper, Lussi som lytter - eller hva vi nå måtte komme på at de kunne få lyst til å leike. Og vi ville kanskje ha latt den stillferdige få si «Nå er det nok!» eller «Nei!» til de som går for langt, og latt de som roper og skriker unødvendig, få prøve lytte-hviske-modus.

Om vi hadde fortsatt å fortelle, ville vi sannsynligvis også ha tatt med at Janne når det byr seg anledninger, siterer fra boka og oppmuntrer til fortsatt bruk av sammenlikninger, overdrivelser, gjentakinger, derunder anaforer (starte flere linjer nedover med samme ord, som det er eksempel på i fortellinga). Vi ville også ha latt henne ta vare på ord og uttrykk som plutselig kommer ut av barnemunn, skrive dem ned, sette dem opp som dikt, henge dem på veggen, lese dem opp, i det hele tatt vise at hun verdsetter barnas kreativitet. Og kanskje kunne Janne og barna finne på å dramatisere scener fra boka og filme, eller de kunne lage ei ny bok, for eksempel om hvordan det går videre med Lussi.

\section{Barn, barnehagelærer og bok: aktørene i fortellinga}

Aktørene i fortellinga vår er de seks barna, barnehagelærer Janne og boka Snill. De spiller en viktig rolle, på hver sin måte, hver for seg og sammen. Boka er avgjørende for hvordan fortellinga utvikler seg, men fortellinga kunne ha blitt helt annerledes med andre barn og en annen voksen.

Barna er forskjellige, slik barna i ei gruppe gjerne er, både når det gjelder språklig og kulturell bakgrunn, og på andre måter. Ei av jentene, Mari, sier ikke så mye. Kanskje har hun en eller annen type språkproblem, kanskje er hun bare litt stille som person. Samanthas forsiktige og korte innspill kan forklares med at hun ennå ikke har lært seg så mye norsk, men kan også ha andre grunner. Flere av Hassans formuleringer avslører at norsk ikke er morsmålet hans, men han får klart fram hva han mener. Vi har tenkt oss Aleksander, Ingrid og Martin som barn med norsk som morsmål, men det er ikke utenkelig at femåringer med andre morsmål kan være like gode i norsk som de er.

Fortellinga tyder også på at barna er forskjellige når det gjelder litterasitet. Mari leser moras navn som ordbilde (helordslesing). Martin gjenkjenner mange ord. Kanskje leser han dem som ordbilder, men det kan også tenkes at han leser iallfall noen av ordene ved å kople bokstaver til lyder og trekke 
dem sammen til ord (fonologisk lesing). Alle barna kommer med innspill som viser at de er engasjerte og følger med på sammenhengen i boka, både gjennom tekst og bilder. Samla er de som et panel eller en liten litterær salong, og noen kommer med spesielt sjølstendige innspill. Også på dette punktet er Martin kanskje den som er kommet lengst, iallfall når det gjelder å uttrykke seg på norsk.

Janne viser gjennnom respons på barnas innspill at hun er svært oppmerksom på forskjeller mellom barna. Hun har blikk for hva den enkelte trenger av bekreftelse og utfordring. Hun framstår i fortellinga som svært bevisst på hvordan hun arbeider med bøker. Hun er engasjert i boka og presenterer den på en måte som skaper forventninger, og legger fra første stund opp til at barna skal være medlesere av både bilder og skrift.

Hun er ikke en voksen som bestemmer hvordan barna skal oppfatte og oppleve boka, men lager rammer som åpner for barnas egne innspill og bekrefter, forsterker og utfyller det barna sjøl sier. Hun hjelper barna til å være handlende personer. Hun legger til rette for at spillet i det vesentlige skal foregå mellom barna og boka, lager rom for forbindelser både mellom boka og det enkelte barnet og forbindelser mellom barna. Det blir et litterært fellesskap.

Janne handler ut ifra en bevissthet om hvordan litterære samtaler kan være, hva ei bok er, hva som er særpreg for ei bildebok, hvordan sjangeren fantastisk fortelling er, hvordan poetiske uttrykksmåter kan være, hvordan boka Snill er.

Boka Snill har fått hovedrollen i fortellinga vår. Det er den som driver handlinga framover og lager bølger i rommet med utagerende leik og sterke utbrudd. Boka blir ikke redusert til et middel til å oppdra, belære eller underholde. Boka får folde seg ut som en verdi i seg sjøl med sitt ytre og indre. Estetiske kvaliteter får komme til sin rett.

Boka er med i fortellinga som fysisk gjenstand og mer enn det. Bøker er materielle ting. Vi kan ha dem i fanget, kjenne på dem, lukte på dem og se på dem, se bilder, bokstaver og ulike typer skrift. Bøker har forside og bakside, kan snus og vendes på og blas i. I fortellinga vår er det fysiske og utvendige ved boka start og inngang. Det er også oppmerksomhet rundt at boka har tittel, forfatter, tegner og forlag. Bøker er oftest i flere eksemplar, og de kan gi felles og individuell opplevelse. Slik er det viktig i fortellinga at barna har hver sitt eksemplar av boka. Bøker kan gi estetiske opplevelser, framkalle forestillinger om det som ikke er her og nå, vekke følelser, få oss til å le, fantasere, tenke logisk, handle. Bøker kan gi oss kunnskap om det vi ikke vet noe om, og opplevelser som sitter $i$ kroppen lenge etterpå. Ei bok kan minne om ei anna bok, slik vi ser på slutten av fortellinga. Å bli fortrolig med det som er gjennomgående for bøker, hører med til litterasitetsutviklingen i et samfunn der bøker spiller en viktig rolle ${ }^{4}$.

Snill er ei bildebok. Ei bildebok er en sammensatt tekst, der ord og bilder fungerer sammen, er en helhet. Når barna får sitte med hver sitt eksemplar av boka, får de møte tekst og bilder samtidig. De kan se bildene mens de lytter til orda, og får dermed oppleve bildeboka som det den er. Ved å la barna ha hver si bok, gjør Janne dem til medlesere før de kan lese i tradisjonell forstand. Det er først og fremst bildene de kan lese, men med boka foran seg kan de også se skrifta, og Janne er tydeligvis interessert $i$ at de skal legge merke til skrift.

Bildene i boka er både enkle og komplekse. De anskueliggjør personene og den ytre konkrete handlinga. Detaljene er få, men symbolmettede. Dette er en symbolikk som nok først og fremst er myntet på og vil bli oppfattet av voksne, men som samtidig vil trigge barns fantasi. Den karikerende og burleske tegnestilen vil antakelig appellere enda sterkere til barn enn til voksne.

\footnotetext{
${ }^{4}$ Ikke alle samfunn som bruker skrift, har bøker (Scribner og Cole, 1981).
} 
Snill er ei fantastisk fortelling. I stort og smått innholder den hendinger, handlinger og tilstander som ikke er mulige i den ytre verden. Denne måten å skrive på får fokus ved at påstanden om at alt går an i bøker får komme igjen flere ganger, etter hvert også i barnas munn.

Snill er ei poetisk bok med svært differensiert bruk av språk og litterære former. Det er henvendelser til leseren, uvanlige sammenlikninger, oppramsinger, bevisst bruk av klisjéer, personifisering, gjentaking av lyder, av ord og av konstruksjoner, metaforer, utrop, setningsemner i fleng, uvanlige måter å gradere på, spesielle årsak-virkning-sammenhenger, fantastiske element, nyskapte sammensetninger, forsterking ved hjelp av gjentakingssammensetninger, kompresjon av handlingselement, overdrivelser med tall og reaksjoner og geografiske avstander, paradoksale sammenlikninger, følelsesutbrudd, korte linjer, knappe spørsmål, bruk av personnavn fra forskjellige tider, velklang, taktfast rytme, bokstavrim, vriding på gamle uttrykk. Dette styrer bruken av boka i fortellinga vi har laga. Barna reagerer på noe av det, og Janne lar formene bli produktive ved at barna skaper mer etter samme mønster. Språkbilder i boka blir til kroppslig leik som igjen får bli ord og begrep og ny leik. Det blir en sløyfebevegelse fra språklig form til kropp, bevegelse og rom og så tilbake til språklig form osv.

Boka har mye tekst. I voksnes vanetenkning er det gjerne slik at mye tekst anses som vanskelig, mens lite tekst er enkelt. Slik er det ikke nødvendigvis. Ordforrådet består i hovedsak av konkrete og kjente hverdagsord for vanlige gjenstander, fenomener og handlinger. Syntaksen er enkel og har et muntlig preg. Og det er mye gjentakelser; samme ord, uttrykk og setninger gjentas og gjentas. Det gjøres på en leikende og poetisk måte, som etter hvert får noe nesten suggererende over seg. Dette, sammen med alle overdrivelsene og den stadige insisteringen på hvor snill Lussi er, skaper en ironisk tone i boka. Sjøl femåringer kan bli mistenksomme her.

Språket er, som resten av boka, både enkelt og krevende, og kan derfor passe for de barna som trenger å befeste og utvide «hverdagsspråket» sitt. Samtidig kan alle glede seg over gjentakelser og regle-liknende sekvenser der det leikes med lydelementer, og noen vil legge merke til sammenlikninger, besjeling og metaforer. Barnehagelæreren legger opp til gledesfylt språkleik på flere plan, ikke som isolerte øvinger, men i en sammenheng som er meningsfylt for barna ${ }^{5}$, og som samtidig gir muligheter for å høre ord og formuleringer fra boka om og om igjen. Den enkle syntaksen, de korte linjene og alle gjentakelsene av ord og uttrykk inviterer til helordslesing. Språkleken bidrar til utvikling av språklig bevissthet, blant annet bevisstheten om språklyder (fonologisk bevissthet), og både denne typen språklig bevissthet og helordslesing har betydning for læring av skriftsystemet ${ }^{6}$.

Snill er ei bok der sansing og kropp er med hele veien og er verdsatt: $i$ tegningene, $i$ handlinga, $i$ språkbildene. Det viser seg i samtalefokus og aktiviteter ellers i bokstunda. For eksempel tydeliggjør og utnytter Janne den nære forbindelsen mellom fantastiske element og metaforiske uttrykk i litterære tekster og barns helt vanlige leik. Litterære former som voksne kan synes er moderne og fremmede og rare, får slik komme ut i rommet som kropp og bevegelse og spill. Janne kan da håpe at disse barna seinere blir voksne lesere som kan ta imot og glede seg over mange slags litterære tekster. Dessuten er det et poeng i seg sjøl at den litterære teksten plutselig får fungere nesten som en danse- eller dramainstruks: Barna kan "stange med hodet" og "bli til en okse" eller være som tordenvær.

Snill er spesiell også i tema. Hovedpersonen, Lussi, er så snill og stille at hun til slutt går i ett med tapetet og forsvinner inn i veggen. Det er likevel ikke verre enn at hun blir savnet, og det settes i gang

\footnotetext{
${ }^{5}$ Se Hansen-Møllerud (1996) for mer om språkleik med barn.

${ }^{6}$ Se Valvatne og Sandvik 2002/2007, kap. 6, om hvordan voksne kan følge opp barns interesse for skrift og gryende fonologiske bevissthet.
} 
store leteaksjoner. Men det er først når hun sjøl greier å hente ut det store protestbrølet, at hun blir synlig igjen. En av grunnene til at barnehagelæreren, Janne, har valgt boka, kan være at et par av jentene i gruppa er stille og tilbakeholdne, kanskje litt for tilpasningsdyktige.

Boka har en konkret ytre handling som trolig vil engasjere de fleste. Og når barna blir kjent med den, vil de kanskje oppfatte flere nyanser. Boka problematiserer den tilvante snill-slem-polariseringen på en underfundig måte som kanskje ikke alle femåringer er mottakelige for i første omgang. Men det er en problematikk som alle femåringer kan antas å ha et forhold til.

Boka nyanserer polariseringa. Etter utstillinga av den altfor føyelige væremåten ser vi både en nødvendig sprenging av denne rollen og en stillferdig og lyttende væremåte etterpå. Dette kan være utgangspunkt for samtaler om at noen ganger er det fint å være på én måte, andre ganger på en annen måte. For den som alltid har vært stille, kan det være fint å prøve en mer utagerende versjon av seg sjøl. Janne lar barna identifisere seg med hovedpersonen i boka og rope ut en sterk protest. Ungene får bli kjent med personen i boka ved å gå inn i hennes handling. Det er noe av det skjønnlitteratur har å by på: erfaring med andre måter å være på og handle på enn dem vi ellers kjenner til. For den som alltid uttrykker seg høylytt og tydelig i rommet, kan det være en verdi å erfare og by på en mer fredelig og mottakende måte. Å utvide uttrykksrepertoaret sitt slik er også ei side ved utvikling av språklig kompetanse.

Vi har valgt Snill som bokeksempel. Andre bøker har andre tema, som åpner for andre muligheter i ei barnegruppe. Det mer allmenngyldige er at barnehagelæreren fanger opp nyansene ved temaet $\mathrm{i}$ boka og lar det styre måten hun bruker boka på.

\section{Hva er det vi gjør når vi dikter ei bokstund?}

Det er vanlig å bruke eksempel for å illustrere poeng i ei faglig framstilling, legge inn biter fra virkeligheten eller eksempel konstruert for formålet. Vi har tatt steget ut til å dikte opp ei sammenhengende fortelling. Emnet for artikkelen får slik framstå i to ulike skikkelser: fiksjon og sakprosa. At vi har vært tre forfattere med noe ulik skriftlig legning og ulike faglige tyngdepunkt, har gitt en del av energien til å strekke artikkelen i flere retninger.

Kan vi lage en fiksjon for å vise fram og forstå hvordan virkeligheten kan være? Denne artikkelen tar for seg bruk av ei skjønnlitterær bok, nemlig ei fortellende bildebok, og inkluderer skjønnlitterær form i framstillinga av det faglige: Vi har brukt vår egen oppdikta fortelling for å kunne formidle erfaringer og kunnskap om tidlig litterasitet på en fortetta, kompleks, sammenhengende og levende måte. Samtidig har fortellingsformen vært et verkt $\varnothing y$ for oss til å oppdage muligheter og få ny innsikt i litterasitet. På den måten har vi også fått prøvd ut og antyda hvordan en kan bruke fiksjon $i$ fortellingsform for å få ny erkjennelse - dette kan peke ut over det spesifikke eksemplet med bok og litterasitet som vår fortelling holder seg innafor.

Vi har dikta opp ei fortelling for å (1) formidle noe om et saksfelt og (2) oppdage muligheter og forstå mer av dette feltet, og for å (3) vise og drøfte hvordan det fungerer å bruke skriftlig fortelling på en slik måte. Det å skrive ei fortelling blir altså en metode.

Saksfeltet er tidlig litterasitet, og nærmere bestemt: måter å arbeide med bøker på i ei barnegruppe. Gjennom å dikte har vi fått til et møte mellom barn og ei bok. 
Fiktiv fortelling bygger på kunnskap og erfaring og gir kunnskap og erfaring til den som skriver, og til den som leser. Ved å lage fortelling får vi frihet til å utforske muligheter. ${ }^{7}$ Vi har kunnet bringe inn hva som helst. Fortelling gir erfaring med væremåter og handlemåter. Slik erfaring gir muligheter for utvidelser av praksis i virkeligheten.

Vi har kopla sammen ei tenkt barnegruppe, en barnehagelærer og ei bok; dette er de tre aktørene. Vi har latt boka med tekst og bilder få en sentral plass, vi har vevd den inn i fortellinga, slik som den også får en sentral plass i barnehagerommet vi har dikta opp. Boka skal framstå tydelig i barnegruppa og i fortellinga, altså for barna i barnegruppa og for leseren av artikkelen. Underliggende er det at selve boka er enestående og viktig.

Fortellinga vår viser hvordan møtet mellom ei bok og ei barnegruppe med voksen leder kan være. Den viser hvordan en kan la møtet med boka bli styrt av det som er spesielt ved akkurat den boka som er valgt: i dette tilfellet at det er ei bildebok, ei fantastisk fortelling, ei bok med poetiske trekk, og at personene og handlinga i boka er akkurat som de er. Fortellinga viser mange muligheter som ligger i bøker generelt og i bildeboka Snill spesielt med tanke på lesestund.

Å se for seg og forstå hvordan virkeligheten kan være, innebærer i neste omgang å kunne skape en virkelighet. Vi har ikke laga en plan for bruken av ei bok i ei barnehagegruppe, men ei fortellende utforsking av muligheter kan også munne ut i en plan. Ved å skrive ei fortelling kan en planlegge ei samlingsstund $\mathrm{i}$ en barnehage eller for den del en annen aktivitet, for eksempel en tur eller noe helt annet. Tenk bare på hvordan vi ofte i livet ser for oss hendelser i framtida, lager skrekkvisjoner, finner løsninger inni hodet, konstruerer lange samtaler med andre. Det er noe vi gjør for å finne ut av ting; vi går gjennom muligheter. Vi dikter opp indre fortellinger også i vår egen virkelighet.

Fortellinga vår er ikke kopi av noe som har skjedd. Å skrive fiksjon er å produsere egne data - og å la data bli produsert. Våre data bygger på kunnskap og erfaring som angår emnet for fortellinga. De bygger også på litterær kunnskap og erfaring. Dessuten kan en litterær form i seg sjøl være ei kraft som fanger og gir sitt. Jamfør de utallige ganger forfattere har sagt at personene i boka begynner å leve sitt eget liv. I dette tilfellet har vi laga ei forholdsvis forsiktig fortelling. Det er likevel ikke slik at vi bare har brukt fortelling for å illustrere det vi på forhånd visste at vi ville ha fram. Vi har etter hvert fått ideer om hva vi ville vise og gi eksempel på.

Vi har til en viss grad latt fortellinga gå sin gang. Og så, i etterkant, kan vi som forfattere se at barnehagelæreren sier og gjør ting som vi ikke helt vet hva hun vil med. Hvorfor sier hun for eksempel "vi" og ikke "dere" når hun snakker om å rope og være stille? Og hvorfor er hun plutselig klart normativ? Her har vi ikke tenkt gjennom alternativ på forhånd og bestemt oss for hva vi ville velge. Etterpå kan vi tenke oss at hun vil lage et fellesskap mellom alle i rommet, at hun vil inkludere seg sjøl. Da er det at vi oppdager at hun ellers i liten grad inkluderer seg sjøl. Janne står utenfor og trekker i trådene og styrer vennlig dialogen mellom boka og ungene. Hun er engasjert i boka, men hun går ikke inn og setter seg sjøl på spill. Hun forteller ikke hvordan det er når hun er sint; hun dikter ikke sammenlikninger eller metaforer om den utagerende Lucy.

Det kan altså bli en dialektikk mellom fortelling og forståelse, det kan gå fram og tilbake. Data/fortelling/fiksjon er noe vi har produsert, men også noe som kommer tilbake til oss, gjør noe med oss. Det skjer noe i skapingsprosessen, vi får noe ekstra.

Det er mange alternativ innafor fiktiv framstilling. Når vi ser på valgene vi har gjort blant flere alternativ, ser vi samtidig flere muligheter, hva andre kan velge. Vi har pekt på ett av valgene i selve skriveprosessen: Skal tanken komme først og fiksjonen som illustrasjon etterpå? En radikalt annen

\footnotetext{
${ }^{7}$ Ikke sjelden uttaler skjønnlitterære forfattere at skrivinga er ei utforsking av fenomen, for eksempel sier Hanne Ørstavik at å skrive I mørket på terrassen var en utforsking av kjærligheten.
} 
prosess ville det være å la fortellinga i stor grad utvikle seg fritt og se hva slags stoff til ettertanke som da oppstod. Vi har fors $\varnothing$ ksvis laga ei fortelling med en eksemplarisk førskolelærer; dette gir det hele et utopisk preg. Vi har holdt oss til en enkel fortellingsform: Handlinga utspiller seg innadørs i en barnehage i løpet av ei samlingsstund, det er få personer med, replikker driver handlinga framover, handlinga er kronologisk og følger gjennomgangen av ei bildebok. Det er ingen store konflikter, ingen dramatiske situasjoner eller tydelige vendinger, utover dramtikken i boka. Synsvinkelen er stort sett utenfra. Slik sett har vi ikke gjort store sprang bort fra en rapportform. Det fins ikke fantastiske element i vår fortelling, slik som det er i boka. Poetiske drag eller diktform har vi heller ikke latt oss smitte av.

Vi har altså gjort sterke avgrensinger innafor det skjønnlitterære. Disse begrensningene er ikke sjølsagte. Hvordan ville det bli om en tok seg enda større friheter? Her ligger det mange muligheter.

\section{Tidlig litterasitet: perspektivutvidelser i fagfeltet}

I nyere norsk litteratur om barnehagens og skolens arbeid med muntlig og skriftlig språk finner en av og til det engelske ordet «literacy» eller fornorskinga «litterasitet» i stedet for ord som var vanlige tidligere, som «skriftspråkskompetanse» og «skriftkyndighet». Disse ordene får bare fram noe av begrepsinnholdet i "literacy". Ett problem er at «literacy» omfatter både det å kunne lese og skrive, mens de norske oversettelsene lett koples bare til skriving. Problemet kunne løses ved bruk av sammensetninger der både det reseptive og det produktive i litterasitetsbegrepet er med, for eksempel «lese- og skriveferdigheter». Men dette blir tungt, og også slike uttrykk har for mange en snevrere betydning enn «literacy» har i forskningen om tidlig litterasitet (eng. «early childhood literacy», eller "early literacy»). Vi ønsker oss en fagterm som signaliserer tilknytning til denne forskningen ${ }^{8}$. Det er vanskelig å oversette literacy, og noen velger derfor å bruke det engelske ordet (se f. eks. Hopperstad, 2005; Karsrud, 2014). Vi mener det er bedre å bruke en norsk form.

Den engelskspråklige forskningen om tidlig litterasitet starta omkring 1970, utvikla seg raskt til et stort forskningsfelt, og ga nye perspektiv på barns forhold til skriftspråk (Gillen og Hall, 2012). Fram til da hadde forskningen vært konsentrert om lese- og skriveopplæring i skolen og leseforberedende $\emptyset$ vinger (eng. «reading readiness exercises»). Men mot slutten av 1960-tallet begynte forskere å interessere seg for barns, også små barns, erfaringer med og interesse for lesing og skriving utenfor skole og barnehage. De observerte at barn utforsker og prøver å finne mening i skrift i miljøet («environmental print»), dvs skrift på skilt, aviser, bøker mm, og bruker skrift til sine egne formål lenge $f ø r$ de har lært seg et skriftsystem. For eksempel gjenkjenner de navn på T-banestasjoner, skriver navnet sitt, kanskje også andre ord, på tegningene sine, skriver brev med skriverabling eller kombinasjon av skriverabling og bokstaver, blar i bøker og snakker om hva som står der.

Forskningsinteressen for tidlig litterasitet gikk mye lenger enn til barns utforsking og bruk av skrift. Oppmerksomheten ble også retta mot små barns muntlige kommunikasjon, og mot sider ved den som en ikke hadde vært så opptatt av før. For eksempel ble leik med språklyder sett i sammenheng

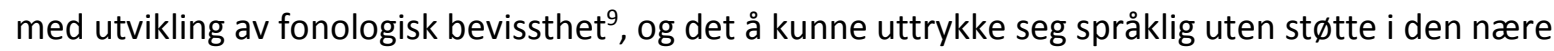
konteksten ${ }^{10}$, og å finne mening og sjøl uttrykke seg i ulike sjangrer (fortelling, forklaring, dikt mm)

\footnotetext{
${ }^{8}$ Forskningen fikk innflytelse i Norge fra slutten av 1980-åra, mye takket være Bente Eriksen Hagtvet (1988) og Rutt Trøite Lorentzen (1991)

${ }^{9}$ Fonologisk bevissthet er bevissthet om språklyder, og nødvendig for å lære seg et alfabetisk skriftsystem.

${ }^{10}$ I litteratur om barns språk omtales ofte det å kunne uttrykke seg klart om noe som er utenfor situasjonen her og nå som å kunne bruke språket situasjonsuavhengig, eller dekontekstualisert (av og til popularisert til der-ogda-språk). Dette er uheldige ordvalg, for språklige ytringer må alltid ses i sammenheng med konteksten de inngår i. Såkalt situasjonsuavhengig språk er egentlig språk som er tilpassa situasjoner der en snakker om noe
} 
ble sett som vesentlig for å kunne finne mening i og sjøl uttrykke seg i skriftlig kommunikasjon. Derfor var det av interesse å se på kommunikasjonen i mange forskjellige situasjoner, både situasjoner der barn får direkte erfaringer med språket i skriftlige tekster (som i bokstunder) og situasjoner med bare muntlig språk, som rollelek og samtaler.

Etter hvert ble perspektivet utvida fra barns språklige kommunikasjon til hele deres kommunikative repertoar, også hvordan de finner mening i og uttrykker seg gjennom tegning, bevegelse og andre former for nonverbal kommunikasjon ${ }^{11}$. Forskere som brakte inn dette perspektivet var inspirert av sosialsemiotisk teori, der meningsskaping og kommunikasjon ses som det sentrale ved både språk og andre tegnsystem ${ }^{12}$. Slik tenkning fikk ifølge Gillen og Hall (2012) først innflytelse på forskning om barns litterasitet mot slutten av 1990-tallet, med boka Before Writing av Günther Kress (1997). Kress hevder i denne boka at vi ikke kan "forstå hvordan barn finner veien inn i skrifta uten å forstå hvordan de skaper mening"13. Han utdyper med å si at barn skaper mening på mangfoldige måter, og at "ulike måter å skape mening på involverer kroppens kontakt med verden på ulike måter - ikke bare syn, som med skrift eller hørsel, som med tale, men berøring, lukt, smak, følelse."14. Han ser alle disse formene for meningsskaping som likeverdige, som vesentlige for menneskets forståelse av verden, og advarer mot ensidig vektlegging av det verbale. I pedagogisk arbeid med kommunikasjon må alle former for meningsskaping verdsettes og oppmuntres, mener han, og framholder mangfoldet av uttrykksformer i multikulturelle samfunn som den viktigste ressursen for kulturell nyskaping $\mathrm{i}$ dagens samfunn (ibid:163).

En annen viktig utvidelse av perspektivet kom før påvirkningen fra sosialsemiotiske perspektiver, fra forskere som primært var opptatt av å se litterasitet $\mathrm{i}$ en videre kulturell sammenheng. Det hadde lenge vært klart at barns miljø utenfor skolen spilte en rolle for forholdet deres til skriftlig språk, men familien ble «først og fremst sett på som en tjener for skolen ${ }^{15}$. Det var skolens oppfatning av litterasitet som rådde grunnen, og om barn ikke oppfylte skolens forventninger, regna en ofte med at de kom fra ressursfattige miljø. Tidligere forskning hadde vist sammenhenger mellom lese- og skriveferdigheter og sosio økonomisk status, men nå begynte forskere for første gang (ifølge Gillen og Hall, 2012:9), inspirert av sosiologisk, sosiolingvistisk og antropologisk forskning, å unders $\varnothing$ ke i detalj litterasitetspraksis (eng. literacy practice) i barns familier og nærmiljø, og spørre hvilken innvirkning barns kommunikative erfaringer utenfor skolen kunne tenkes å ha på deres forhold til lesing og skriving i skolen.

En av forskerne Gillen og Hall nevner i denne sammenhengen, er Shirley Brice Heath, som i boka Ways With Words (1983), med undertittelen Language Life and Work in Communities and Classrooms, skrev om sine observasjoner over en tiårsperiode i et svart og et kvitt

utenfor den konkrete kommunikasjonssituasjonen. Monica Axelsson (2005:92) skiller mellom å kontekstualisere språklig og kontekstualisere situasjonelt. Vi syns hun på den måten får fram skillet mellom å tilpasse språket til situasjoner der en må skape kontekst ved hjelp av verbalspråklige virkemidler, og å tilpasse det til situasjoner der en ikke trenger så mange ord for å få fram det en mener.

${ }^{11}$ Vi viser til Hopperstad (2005) for et norsk forskningsarbeid som ser nonverbale uttrykksformer i et litterasitetsperspektiv.

${ }^{12}$ Ordet semiotikk kommer fra det greske ordet semeion, som betyr 'tegn'. Sosialsemiotikere ser verbalspråk og andre tegnsystem (for eksempel i trafikkskilt, musikk og billedkunst) som sosiale. Det betyr at de har sin opprinnelse i og utvikler seg gjennom kommunikasjon mellom mennesker (Maagerø 2005:25).

${ }^{13}$ Vår oversettelse av "understand how children find their way into print unless we understand the principles of their meaning-making." (Kress, 1997:xvii)

${ }^{14}$ Vår oversettelse av "Different ways of making meaning involve different kinds of bodily engagement with the world - that is, not just sight as with writing, or hearing as with speech, but touch, smell, taste, feel." (Kress, 1997: xvii)

${ }^{15}$ Vår oversettelse av "the role of the home was essentially positioned as a handmaiden for schooling" (Gillen og Hall 2012:8) 
arbeiderklassemiljø i Sør-Carolina i USA, og sammenlikna barns kommunikative erfaringer i disse miljøene med erfaringene til barn i middelklassefamilier med relativt høyt utdanningsnivå. En viktig motivasjon for forskningsarbeidet var at barn fra miljøer med høyt utdanningsnivå i gjennomsnitt hadde langt bedre skoleresultater enn barn fra de to andre miljøene. Særlig dårlig gikk det for barna fra det svarte arbeiderklassemiljøet. Heath mente en vesentlig del av forklaringen på disse forskjellene kunne være at skolen forutsatte erfaringer med muntlig og skriftlig språk som bare noen barn hadde. Barn som ikke hadde disse erfaringene, ble ofte vurdert å ha behov for spesialpedagogisk hjelp - og fikk opplæring som passa dårlig for dem. Forskningsarbeidet, som også inkluderte observasjon i skolen og utprøving av nye arbeidsmåter der, overbeviste henne og mange andre om at hun hadde rett. Gjennom boka si og artikler både før og etter at boka kom ut, har hun vist hva forskjeller i kommunikative erfaringer kan bestå i, og hvor viktig det er for barns litterasitetsutvikling at pedagogene er oppmerksomme på, verdsetter og bygger videre på ressursene barna bringer med seg fra familie og nærmiljø. Det er tankevekkende at barna i det svarte arbeiderklassemiljøet Heath beskriver, vokste opp i et frodig språkmiljø der treffende formuleringer, dramatisering og rim, klang og rytme var verdsatt. Heath hevder at små barn fra dette miljøet hadde fortelleferdigheter og en språklig kreativitet som først ble etterspurt høyere oppe i skoleklassene når en begynte å arbeide med estetiske uttrykksformer. Men da var mange av barna falt av lasset for lenge siden $^{16}$.

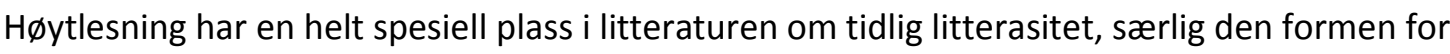
høytlesning som kalles dialogisk høytlesning, der høytleseren på ulike måter gir rom for og følger opp innspill fra barna. I fortellinga har vi lagt vekt på å få fram det dialogiske, fordi vi er overbevist om at når barn får være medlesere av ord og bilder og komme med innspill til det som blir lest for dem, begynner de tidlig, ja, lenge $f ø r$ de kan lese eller skrive i tradisjonell forstand, å utvikle en litterasitet som omfatter mer enn begynnende innsikt i skriftsystemet. De begynner også «å kunne ta stilling til og vurdere kritisk budskapet i ulike tekster» og å få «innsikt i de muligheter ulike uttrykksformer gir for meningsskaping». Formuleringene er henta fra en artikkel av Marit Hopperstad (2005:79), og vi er enige med henne $\mathrm{i}$ at de dekker vesentlige aspekter ved litterasitet. Men de må suppleres med et opplevelsesperspektiv. Opplevelse av tekster, også opplevelse av at ulike uttrykksformer, er med på å gjøre en tekst til det den er, og hører med til både barns og voksnes litterasitet. Derfor har vi latt både tekst og bilder i Snill få stor plass. Vi ville vise hvordan Janne understreker stemninga i tekstsekvenser og bilder, blant annet gjennom stemmebruk og pauser, og hvordan hun fokuserer på det særegne ved skjønnlitterære tekster og ved uttrykksformer i akkurat denne boka. Barna kan oppleve at "alt går an i bøker», og de kan oppdage at deres egne uttrykk kan bli rytmiske og morsomme små dikt å glede seg over. Dette er noe annet enn å ta stilling til budskap og ha innsikt i uttrykksformer (jf sitatet ovenfor fra boka til Hopperstad). Slike lesestunder betyr litterære opplevelser for barna, opplevelser som er viktige for mange sider ved livet deres her og nå, og som de kanskje vil hente fram igjen mange år seinere. Lesestundene kan ha stor betydning for deres forhold til tekster, både nå og i framtida. Å lytte til og være med på å skape poetisk språk, som barna gjør i bokstunda vår, retter oppmerksomheten mot estetiske kvaliteter som en helt egen verdi.

Barn som får være med å ta imot og skape tekster av mange slag, muntlige og skriftlige, der bilder og andre nonverbale uttrykksformer tas i bruk, begynner tidlig å utvikle en litterasitet som innebærer å ha glede og nytte av mange slags tekster, skjønnlitterære og andre, å kunne forholde seg sjølstendig til dem, og å kunne uttrykke seg på forskjellige måter. De får et repertoar for å ta imot tekster og et

\footnotetext{
${ }^{16}$ Vi viser til Valvatne og Sandvik (2002/2007), kap. 2 og 5, for grundigere orientering på norsk om Heaths forskning, og anbefaler artiklene hennes fra 1982 og 1986. Vi vil også gjøre oppmerksom på boka Words at work and play. Three decades in family and community life, som forteller hvordan det har gått videre med noen av barna i de to arbeiderklassemiljøene - og med barna og barnebarna deres. Til slutt vil vi nevne at hun er medforfatter av ei bok om etnografiske tilnærminger til forskning om språk og litterasitet (Heath og Street, 2008).
} 
repertoar for å uttrykke seg, aleine eller i fellesskap. Dialogiske bokstunder og lydhørhet overfor barns uttrykk av alle slag kan bidra til at barn fra ulike miljø og med ulike forutsetninger for språklig kommunikasjon kjenner uttrykksglede, får «myndighet til å delta aktivt i kommunikative situasjoner» og «mulighet til å prege meningsutveksling og ta stilling til budskapet i et bredt spekter av tekster» (ibid).

Mange er opptatt av hva barnehagen kan gjøre for å forebygge lese- og skrivevansker. Andre mener arbeidet i barnehagen skal være retta inn mot barna her og nå, ikke mot hva de skal bli i framtida. $\mathrm{Vi}$ er overbevist om at arbeid med litterasitetsutvikling er en viktig oppgave, men ser det som vesentlig at arbeidet rettes inn mot barnas liv her og nå, og bygger på en vid forståelse av barns litterasitet. Det er ved å være oppmerksom på barns mangfold av uttrykksformer, ikke ved å se etter bestemte tegn på litterasitet, som for eksempel bruk av bokstaver eller trekk ved muntlig språk, at en kan få til en kommunikasjon som oppleves meningsfylt for barn her og nå. Og det er først da kommunikasjonen kan få stor betydning for framtidig lesing og skriving.

\section{Sluttord og mer som kan skje}

I denne artikkelen har tidlig litterasitet vært utgangspunktet vårt for å utforske gjennom fiksjon og drøfte faglig hvordan en kan arbeide med ei bildebok i ei barnegruppe. Dermed har vi også fått prøvd ut bruk av fiksjon som metode og hatt utgangspunkt for å gjøre noen metodologiske refleksjoner.

Det har vært et poeng å inkludere mange sider ved tidlig litterasitet, også sider som det i en del sammenhenger er lite fokus på. Kort oppsummert forstår vi med tidlig litterasitet skriftspråksrelatert kompetanse før barn har lært seg å lese og skrive i tradisjonell forstand. Den kan vise seg ved at de utforsker og bruker skrift (reseptivt og produktivt) ${ }^{17}$, er oppmerksomme på språk (lyder, klang, rytme, ordvalg med mer), finner mening i muntlige, skriftlige og sammensatte tekster ${ }^{18}$, tar stilling til meningsinnhold, utveksler synspunkt på det, opplever glede over estetiske kvaliteter i tekster, skaper tekster sjøl. For å legge merke til små barns litterasitet må en være oppmerksom på både hva de sier og hva de uttrykker på andre måter, for eksempel gjennom blikk, kroppsspråk, tegning, bruk av bokstaver osv.

Vi har villet utvide perspektivet på barnehagens arbeid med litteratur ved å lage fortelling om ei lesestund der alle har hver si bok. Vi har prøvd å utforske hvordan barns litterasitet kan komme til uttrykk på flere måter enn ved bare å lytte til høytlesning. Barna kjenner igjen bokstaver, ulike typer skrift og ord, de deltar på ulike måter i samtale der det brukes ord som har med bøker å gjøre (forfatter, illustrat $\varnothing r$, forlag), og viser gjennom sine innspill at de både legger merke til spesielle trekk ved språk og bilder i boka, følger med på handlinga og har sine egne oppfatninger. De leiker med

\footnotetext{
${ }^{17}$ Tidlig bruk av skrift inkluderer også lesing og skriving en periode etter at barn har knekt skriftspråkskoden, det vil si så smått har begynt å bruke prinsippet skriftsystemet er basert på. Et alfabetisk skriftsystem (som det norske og skriftsystemene til de fleste innvandrerspråkene i Norge) er basert på det alfabetiske prinsippet, som er at skrifttegnene representerer lyder i talespråket. Barn har knekket den alfabetiske koden når de begynner å skrive fonologisk (dvs begynner å skille ut enkeltlyder i ord og skrive bokstavene for lydene de oppfatter) eller lese fonologisk (dvs begynner å kople bokstaver til lyder og lese ved å trekke sammen lydene til ord). Mange barn begynner å skrive før de begynner å lese, for det er enklere for barna å lytte ut lyder og kople til bokstaver de kjenner, enn å kople bokstaver i skrift til talespråkslyder og lese ved å trekke lydene sammen (utdypet i Valvatne og Sandvik, 2007:276-277).

${ }^{18}$ Skriftlige og sammensatte tekster er tekster som barna lytter til, eller både ser på (og kanskje leser i) og lytter til, som i bokstunder eller når de ser på TV eller spiller elektroniske spill. Barn produserer også tekster sjøl, for eksempel når de skriver fonologisk eller kombinerer tegning med skriverabling, bokstaver eller fonologisk skriving, eller leiker rolleleik der det inngår skrift (for eksempel skrift på skilt og varer i butikkleik).
} 
språket, spontant og inspirert av Janne, som også sørger for at språkleiken blir til enkle poetiske tekster. Viktig er det at ei bokstund har i seg rom for både fellesskap og individualitet.

Med bokstunda vår ville vi også utforske muligheter som ligger i denne spesielle boka. I ei barnegruppe kan det skje mindre, det kan skje mer, og det kan skje andre ting. Vi har ikke villet ta opp alt smått og stort som kan hende i alle retninger når noen barn og en voksen leser boka Snill sammen. Men det vil være interessant om andre skriver andre fortellinger og gjør fors $\varnothing \mathrm{k}$ med virkelige barn i virkelige barnehager, med utgangspunkt i denne boka eller i andre bøker.

Tittelen på artikkelen er alvorlig ment: Det handler om at barn kan være likeverdige subjekter i en prosess sammen med bøker. Barn skaper i en viss forstand sin egen tekst når de lytter til høytlesning, som voksne gjør når de leser, og som barnas innspill viser. Barn kan også skape nye tekster med utgangspunkt i boka, som de gjør i bokstunda, og som vi tenker oss at de vil fortsette med etterpå. Forbindelsen mellom barn og bok kan være mer eller mindre kroppslig og romlig: Boka er en ting å sanse i rommet og kan sette barna i uttrykkende og skapende bevegelse. Når vi legger sammen barn og bok, vet vi ikke hva som kommer ut. Det kan by på flere overraskelser enn å legge sammen to og to.

Noen av barna i fortellinga vår er i ferd med å lære norsk som andrespråk, og ei av jentene kan ha språkproblemer. Men alle følger med og kommer med innspill, og vi har pekt på språklige særtrekk ved boka som gjør at dette ikke er helt utopisk. Her vil vi føye til at bokvalg er viktig, ikke minst når en skal lese med flere barn, og noen ganger må en finne fram til bøker som det er lett å forberede barna på med konkrete hjelpemidler, for eksempel ved å lage landskap og personer sammen med barna før en finner fram boka ${ }^{19}$. Når barn strever med å følge med i bokstunder, kan det også være klokt å velge ei bok de kjenner fra før og er glad i, både fordi de da har et godt grunnlag for å følge med, og fordi det er fint å få dele med andre noe en er glad i. Det går også an å fortelle på norsk bøker som er skrevet på andre språk, hvis noen i barnehagen kan det aktuelle språket, eller en kan få hjelp til å oversette ${ }^{20}$. Det kan bety mye for tospråklige barn at bøker på morsmålet deres er med i bokstunder. De kan føle stolthet og glede over å få dele, de kan oppleve å spille en mer sentral rolle enn de ellers gjør, og de kan få vise sine kunnskaper om skrift på morsmålet ${ }^{21}$.

Vi har argumentert for at arbeid med litterasitet er en viktig oppgave for barnehagen, forutsatt at det knyttes til aktiviteter som er meningsfylte for barna og bygger på en vid forståelse av hvordan barns litterasitet kan komme til uttrykk. Mange kommuner pålegger barnehagene å bruke språkkartleggingsverkt øy der språk- og litterasitetsutvikling skal registreres i et skjema. Hensikten er å bidra til forebygging av lese- og skrivevansker. Men den helhetlige forståelsen av tidlig litterasitet som forskere med sosiologisk, sosiolingvistisk, etnografisk og sosialsemiotisk tilnærming har brakt inn i dette forskningsfeltet, forsvinner når litterasitet skal registreres i et aldersinndelt kartleggingsskjema som for eksempel TRAS (Espenakk m. fl., 2011) ${ }^{22}$. Små barns litterasitet gir seg mange slags uttrykk, og spørsmål i et kartleggingsskjema begrenser perspektivet.

I USA er det strengere krav til dokumentasjon enn i Norge. Gillen og Hall (2012) hevder at mye av den engelskspråklige samtidsforskningen om tidlig litterasitet har liten innflytelse på politikernes oppfatning av pedagogisk praksis. Celia Genishi og Anne Haas Dyson gir uttrykk for det samme i boka

\footnotetext{
${ }^{19}$ Slike arbeidsmåter er beskrevet i Sandvik og Spurkland (2012).

${ }^{20}$ Det finnes også barnebøker med tekst på både norsk eller engelsk og et innvandrerspråk. Slike bøker kan lånes fra Det flerspråklige bibliotek ved Deichmanske bibliotek i Oslo, via barnehagens nærmeste bibliotek. ${ }^{21}$ Kenner (2000 a og b) skriver om litterasitetsarbeid i en flerspråklig barnehage (eng. "school") i London, der 45-åringer ble oppmuntra til å ha med seg mange slags tekster på andre språk enn engelsk, blant annet aviser, ukeblader og kalendere.

22 TRAS (Tidlig Registrering Av Språkutvikling) er et kartleggingsverktøy som mange kommuner, blant andre Oslo, pålegger barnehagene å bruke.
} 
Children, Language and Literacy (2009), der de blant annet skriver om krav til dokumentasjon som gjør det vanskelig for pedagoger i USA å ta hensyn til at barn er forskjellige. Boka til Genishi og Dyson viser begrensninger som ligger i styring utenfra, og inneholder mange små fortellinger fra virkeligheten om hva pedagoger med blikk for barns mangfold av uttrykksformer kan gjøre på tross av myndighetenes bestemmelser. Boka kan inspirere til å dikte fortellinger om mange slags arbeid med språk og litterasitet.

Fortellinga er prega av vår språk- og litteraturfaglige bakgrunn. Det er lite om nonverbale uttrykksformer i den. Barna uttrykker seg mest verbalt, og noe kroppslig, men det kommer lite fram om hvordan de forholder seg til bildene. Fortellinga gjenspeiler med andre ord i liten grad den utvidelsen av perspektivet på barns litterasitet som sosialsemiotisk inspirerte forskere har bidratt med. Noe er imidlertid med, blant annet i det vi skriver om hva som kunne ha vært med hvis vi hadde fortsatt med å fortelle om hva som skjedde etter bokstunda. Vi er overbevist om at dette er et perspektiv som må sterkere inn i barnehagens litterasitetsarbeid, fordi det setter kommunikasjon og meningsskaping i sentrum, og gir rom for barns mangfoldige uttrykksformer. Om barnehagelærere i arbeidet med litterasitet retter oppmerksomheten mot barns mange måter å uttrykke seg på, kan de både lykkes bedre med barn som av ulike grunner strever med ord, og bidra til at språksterke barn utvider sitt kommunikative repertoar. Vi oppfordrer til tverrfaglig FoU-arbeid basert på innsikt i at barns litterasitet kan vise seg på mange forskjellige måter.

Vi lar Rutt Trøite Lorentzen, en av pionerene i Norge når det gjelder barnehagens arbeid med litterasitet, få siste ord. Hun ser dette arbeidet som del av et større prosjekt. Slik hun oppfatter det, er «utvikling av skriftspråkleg kompetanse» ikke det overordna målet for pedagogisk arbeid med førskolebarn, «ikkje ein gong for den skriftspråksutviklande verksemda» (hennes kursivering). «Det overordna målet må sjåast i lys av at dei som i dag er førskolebarn, i morgon avgjer jordas framtid», skriver hun videre, og fortsetter: "I eit slikt perspektiv vil det meste fortone seg som ørsmå skritt. Det må vi som pedagogar finne oss i, berre dei ørsmå skritta går i rett retning. Det vil dei gjera dersom den verksemda vi driv, tener til å styrke barns kompetanse og sjølvkjensle - viser barna at skrifta kan vera dei til hjelp i deira eigne livsprosjekt og ei kjelde til oppleving, kunnskap og makt.» (Lorentzen, 1997:214-215).

\section{Litteratur}

Axelsson, Monica (2005): Litteracitetsutveckling i Stockholms flerspråkiga förskolor. I Axelsson, M. m.fl.: Stärkta trådar - flerspråkiga barn och elever utvecklar språk, litteracitet ock kunskap. Utvärdering av Stockholms stads storstadssatsning - målområde språkutveckling och skolresultat (s. 19 - 98). Spånga: Rinkeby språkforskningsinstitut.

Espenakk, Unni m.fl. (2011) TRAS. Observasjon av språk i daglig samspill. Stavanger: Nasjonalt senter for leseopplæring og leseforskning, Universitetet i Stavanger.

Genishi, Celia og Anne Haas Dyson: Children, Language and Literacy. Diverse learners in diverse times. New York: Teachers College, Columbia University.

Gillen, Julia og Nigel Hall (2012): The Emergence of Early Childhood Literacy. I Larson, Joanna og Jackie Marsh: The Sage Handbook of early childhood literacy.

Hagtvet, Bente Eriksen (1988): Skriftspråkutvikling gjennom lek. Hvordan skriftspråket kan stimuleres i førskolealderen. Oslo: Universitetsforlaget 
Hansen-Møllerud, Kari (1996): Det poetiske språket - poetisk språkarbeid med barn. Debattserien for barnehagefolk, nr. 2/96, s. 30-42

Hansen-Møllerud, Kari og Helene Valvatne (2004): Barn + bøker = sant. I Fag, kultur og fellesskap perspektiver på innholdet $i$ barnehagen. Oslo: Utdanningsakademiet 2004. Bedre barnehager skriftserie nr. 1.

Heath, Shirley Brice (1982): What no bedtime story means: Narrative skills at home and at school. Language in Society, vol. 2, s. 49-76 (også publisert i Schieffelin, B.B. og E. Ochs, (red. 1986): Language socialization across cultures. Cambridge, England: Cambridge University Press).

Heath, Shirley Brice (1983): Ways with words. Language life and work in communities and classrooms. Cambridge, England: Cambridge University Press (utg. med ny epilog 1996).

Heath, Shirley Brice (1986): Separating 'Things of the imagination' from Life: Learning to Read and Write. I Teale, W.H. og E. Sulzby (red.): Emergent Literacy: Writing and Reading. Norwood, NJ: Ablex Publishing Corporation.

Heath, Shirley Brice (2012) Words at work and play. Three decades in family and community life. Cambridge: Cambridge University Press.

Heath, Shirley Brice og Brian Street, med Molly Mills (2008): Ethnography. Approaches to language and literacy research. New York: Teachers College Press

Hopperstad, Marit (2005): "Nå skal dere få tegne" Tegningens plass i grunnleggende lese- og skriveopplæring. I Skjong, Synnøve (red.) GLSM Grunnleggjande lese- skrive og matematikkopplæring. Oslo: Det Norske Samlaget.

Karsrud, Fridunn Tørå (2014): Muntlig fortelling i barnehagen. En vei til danning, livsmot og literacy. Oslo: Cappelen Damm Akademisk.

Kenner, Charmian (2000): Home pages. Literacy links for bilingual children. Oakhill, England: Trentham Books Limited

Kenner, Charmian (2000): Biliteracy in a Monolingual School System? English and Gujarati in South London. Language, Culture and Curriculum, Vol. 13, no. 1

Kress, Gunther (1997): Before writing. Rethinking the paths to literacy. London, Routledge.

Lorentzen, Rutt Trøite (1997): Skriftspråkstimulering i førskolealder. I Austad, I. (red.): Mening i tekst. Teorier og metoder i grunnleggende lese- og skriveopplæring (ny, rev. utg.). LNUs Skriftserie nr. 103. Oslo: Landslaget for norskundervisning (LNU) og Cappelen

Maager $\varnothing$, Eva (2005): Språket som mening. Innføring i funksjonell lingvistikk for studenter og lærere. Oslo: Universitetsorlaget.

Sandvik, Margareth og Marit Spurkland (2012): Lær meg norsk før skolestart. Språkstimulering og dokumentasjon i den flerkulturelle barnehagen. Oslo: Cappelen Damm Akademisk.

Scribner, Sylvia og Michael Cole (1981): The psychology of literacy. Cambridge, MA og London: Harvard Educational Press. 
Barn + bok $=? 122$

Valvatne, Helene og Margareth Sandvik (2007/2002): Barn, språk og kultur. Språkutvikling fram til sjuårsalderen. Oslo: Cappelen Akademisk Forlag 